\section{Estimating Popper's impact}

SIR - Skoyles ${ }^{1}$, Bartley ${ }^{2}$ and even Popper himself say that Popper's work has had little impact on professional philosophers. Skoyles ${ }^{1}$ even claims that Popper has failed to influence sociologists and others studying science and society. The view that Popper's philosophy has been widely acknowledged only by scientists stems primarily from Bartley's account $^{2}$ of the development of the profession of philosophy of science and from his personal communications with Popper. However, judging from the references made to Popper in the Science Citation Index $(S C I)$ and the Social Sciences Citation Index (SSCI), this "failure" is grossly overstated.

According to the 1969-77 SSCI, comprising 800,000 source items and nearly 8 million references cited within them, Popper was the third most-cited author in the philosophy and history of science ${ }^{3}$, and his book Logik der Forschung/The Logic of Scientific Discovery (1935/1959) was the second most-cited book in this subject ${ }^{4}$. Of course, this does not directly measure Popper's influence on philosophers per se because the impact of his work could be on scholars in disciplines other than philosophy.

But when we compare the number of articles citing Popper in $\mathrm{SCI}$ (column A in the table), SSCI (excluding philosophy) (B) and SSCI (only philosophy) (C) during 1974-91, his impact in each field has been considerable.

Still, there is an apparently great difference between Popper's impact on the philosophy literature (C) as compared to the science (A) and social-sciences (B) literature. But this difference diminishes when we consider that the total number of ISI-indexed philosophy papers $(50,006)$ is a small fraction of the total in the $S S C I$ file $(2,170,943)$ and the $S C I$ file $(9,741,144)$ during $1974-91$.

Consider also that the annual average citations per cited author in the SSCI file has ranged from 3.4 to 4.4 during this time, and 7.1 to 8.8 in the $S C I$. In comparison, Popper's annual average citation rate in the $S S C I$ was 234.9 , and 79.0 in the $S C I$, during 1974-91. If we take into account only the philosophy

NUMBER OF ARTICLES CITING WORKS BY KARL POPPER

\begin{tabular}{lrrrr}
\hline Years & A & B & C & Total \\
& & & & \\
$1974-76$ & 111 & 447 & 109 & 667 \\
$1977-79$ & 185 & 557 & 175 & 917 \\
$1980-82$ & 240 & 648 & 101 & 989 \\
$1983-85$ & 312 & 686 & 97 & 1095 \\
$1986-88$ & 281 & 572 & 111 & 964 \\
$1989-91$ & 293 & 607 & 119 & 10.19 \\
Total & 1422 & 3517 & 712 & 5651 \\
\hline
\end{tabular}

journals indexed in the SSCI, Popper's annual average citation rate is 39.6 . So, despite Popper's modest estimation of himself, it is easy to agree with Bondi ${ }^{5}$ that "Popper's influence shines through".

\section{B. I. B. Lindahl}

Department of Geriatric Medicine. Karolinska Institute,

S-141 86 Huddinge,

Sweden

\section{A. Welljams-Dorof}

Institute for Scientific Information, 3501 Market Street,

Philadelphia,

Pennsylvania 19104, USA

SIR - It is not surprising that there is no 'Popper' school ${ }^{1}$. First, philosophers of science seem to be more concerned with the nature of reality and truth in general than the special features of science, and, second, Popper's contributions to the understanding of the nature of science seem to be overrated ${ }^{6}$. To his credit he has emphasized the creative aspects of science, but what is usually regarded as his most important contribution - that science proceeds by falsification - has severe limitations.

The basic idea that only falsification is important and one should not merely look for confirming instances was put forward by Claude Bernard in his book on experimental medicine in $1865^{7}$. But science works in a much more complex way, theories and experiments often being intimately linked. The history of science is filled with examples where scientists succeeded because they ignored falsification. Indeed, Gerald Holton $^{8}$ has argued cogently that the graveyard of failed scientists is littered with those who did not practise a suspension of disbelief when their ideas were first shown to be wrong. As Francis Crick said: "A theory that fits all the facts is bound to be wrong, as some of the facts will be wrong".

The theory does not even resolve the problem of induction, for one wants to have a sufficient number of experimental falsifications to be persuaded. The idea also does not distinguish between science and nonscience because absurd ideas such as that eating hamburgers will make you a good poet - are falsifiable. Worse still, Popper's philosophy is at heart relativistic, for there is no real measure of reliability of ideas or use of confirmations, and its emphasis on theory marginalizes empirical discovery.

Finally, consider applying the falsification test to his falsification hypothesis. How would one falsify it? If the evidence of history is not adequate what is? As Popper's champion, Medawar, pointed out, science gets on very well without a philosophy of method.

\section{Lewis Wolpert}

Department of Anatomy

\& Developmental Biology,

University College London.

Windeyer Building,

Cleveland Street, London W1P 6DB, UK

1. Skoyles, J. R. Nature 359, 100 (1992)

. Bartley, W. W. in In Pursuit of Truth (ed. Levinson, P 249-289 (Humanities. New Jersey, 1982)

3. Garfield, E. in Essays of an Information Scientist Vol. 3 (ed. Garfield, E.) 633-639 (ISI, Philadelphia, 1980). 4. Garfield, E. in Essays of an Information Scientist Vol, 3 (ed. Garfield, E.) 621-632 (ISI, Philadelphia, 1980)

5. Bondi, H. Nature 358, 363 (1992).

6. Wolpert, L. The Unnatural Nature of Science (Faber. London, in the press).

7. Bernard, C. Introduction to Experimental Medicine (Macmillan, New York, 1927).

8. Holton, G. The Scientific Imagination (Cambridge University Press, 1978).

\section{Women in science}

SIR - Your leading article "Women in Science" (Nature 359, 92; 1992) cannot go unchallenged. You argue that the proposal by the National Science Foundation to refuse financial support for scientific meetings unless women speakers are included in the programme is misguided, because it will indirectly lead to the conclusion "that women in science are not really as good as men". What nonsense! This conclusion will be reached only if the presentations by women over time are significantly inferior in quality to those of men.

There was no evidence for this at the exciting and stimulating Cold Spring Harbor Meeting on Mouse Molecular Genetics (26-30 August) where a high proportion of the speakers were women. Nor have I obtained this impression from a variety of other conferences in which women have been well represented. On the other hand, as a member of a National Institutes of Health Study Section I have repeatedly been disappointed to see proposals for meetings in which very few women have been invited. Invariably, the organizers of such meetings are well established men, while comparable meetings with women organizers include a reasonable proportion of articulate women doing good science. With time, some change is inevitable but, in my opinion, women have been waiting long enough and are tired of it. If faster change cannot be brought about by persuasion and feedback, as experience suggests, then stronger pressure has be to be applied by funding agencies who want to promote a fair hearing for the women students and investigators they pay to train and support.

\section{Brigid Hogan}

Department of Cell Biology, Vanderbilt University,

Nashville, Tennessee 37232, USA 